\title{
EDITORIAL
}

\section{Fall Issue, 2015}

DOI:http://dx.doi.org/10.5770/cgj.18.214

Hello! Our fall issue contains a wide range of geriatrics research ranging from improving dental health in older adults, ${ }^{(1)}$ to an examination of the association of cognitive test scores and level of function in older adults. ${ }^{(2)}$ Other papers examine the risk factors for developing dementia in older indigenous persons, ${ }^{(3)}$ and provide an overview of outcomes and results of a pre-conference workshop held prior to the Scientific Meeting of the Canadian Association on Gerontology. ${ }^{(4)}$

Finally we are pleased to present the abstracts presented at the 35th Annual Scientific Meeting of the Canadian Geriatrics Society, which was in Montreal this year. ${ }^{(5)}$

Thanks again for your interest!

Dr. Ken Madden

Dr. Mark Rapoport

Dr. Colleen Maxwell

\section{REFERENCES}

1. Khanagar S, Naganandini S, Vasuda, R, et al. Improving oral hygiene in institutionalised elderly by educating their caretakers in Bangalore City, India: a randomised control trial. CGJ. 2015;18(3).

2. Sterniczuk R, Theou O, Rusak B, et al. Cognitive test performance in relation to health and function in 12 European countries: The SHARE study. CGJ. 2015;18(3).

3. Petrasek MacDonald J, Barnes DE, Middleton LE. Implications of risk factors for alzheimer's disease in Canada's Indigenous population. CGJ. 2015;18(3).

4. Montero-Odasso M, Bherer L, Studenski S, et al. Mobility and cognition in seniors. Report from the 2008 Institute of Aging (CIHR) Mobility and Cognition Workshop. CGJ. 2015;18(3).

5. Canadian Geriatrics Society. Abstracts from the 35th Annual Scientific Meeting of the Canadian Geriatrics Society, Montreal, April 2015. CGJ. 2015;18(3). 